\title{
A COMUNIDADE BOA ESPERANÇA/FRUTAL (MG) E OS EQUILÍBRIOS DA UNIDADE CAMPONESA FRENTE AO AVANÇO DO AGRONEGÓCIO CANAVIEIRO
}

\section{THE BOA ESPERANÇA/FRUTAL (MG) COMMUNITY AND THE BALANCES OF CAMPONES UNIT AHEAD OF ADVANCED SUGAR CANE AGRIBUSINESS}

\author{
Heitor Nascimento Mendes \\ Doutorando no Programa de Pós-graduação em Geografia/IG/UFU \\ Membro do Laboratório de Geografia Agrária (LAGEA) \\ Uberlândia, MG, Brasil \\ heitor1001@hotmail.com \\ Marcelo Cervo Chelotti \\ Docente do Instituto de Geografia da Universidade Federal de Uberlândia (UFU) \\ Membro do Laboratório de Geografia Agrária (LAGEA) \\ Uberlândia, MG, Brasil. \\ mcervochelotti@gmail.com
}

\section{Resumo}

Diante da expansão das lavouras de cana-de-açúcar e do agronegócio canavieiro no Triângulo Mineiro, principalmente a partir da década de 2000, observamos novas (re)organizações territoriais que incorporam elementos às estratégias de reprodução social dos camponeses dessa região, estabelecidas a partir da relação entre a lógica corporativa da produção sucroenergética e a agricultura camponesa. A comunidade Boa Esperança, localizada no município de Frutal (MG), tem em seu histórico uma produção camponesa diversificada, porém, o processo de avanço do front canavieiro vem limitando e impondo uma série de transformações e, consequentemente, adaptações no âmbito produtivo e sociocultural das famílias. Esse movimento se evidenciou a partir do ano de 2006, com a instalação de duas usinas do setor no município. Nesse sentido, o presente artigo tem como objetivo avaliar a conjuntura que possibilitou a nova dinâmica observada na comunidade a partir da noção de equilíbrios camponeses proposta por Jan Douwe van der Ploeg, analisando as características das organizações camponesas nessa comunidade, e as estratégias estabelecidas a partir do embate entre o território do capital e o camponês. Nota-se que os aspectos vinculados aos "equilíbrios camponeses" se reorientam a partir da territorialização da usina, dificultando ou muitas vezes impossibilitando a reprodução social desses grupos.

Palavras-chave: Agricultura camponesa. Agronegócio canavieiro. Território. Equilíbrio. Frutal (MG). 


\begin{abstract}
Faced with the expansion of sugarcane and sugarcane plantations in the Triângulo Mineiro, especially since the 2000s, we observed new territorial (re)organizations that incorporate elements to the social reproduction strategies of the peasants of this region, established from the relationship between the corporate logic of sugar-energy production and peasant agriculture. The Boa Esperança community, located in the City of Frutal (MG), has in its history a diversified peasant production, but the process of advance of the sugarcane front has been limiting and imposing a series of transformations and, consequently, adaptations in the productive and sociocultural scope of families. This movement was evident from the year 2006, with the installation of two plants of the sector in the township. In this sense, the current article aims to assess the enabled situation that distanced dynamic observed in the community from the notion of peasant equilibrium, proposed by Jan Douwe van der Ploeg, in order to analyze the characteristics of peasant organizations in this community, such as its strategies combined to the conflicts between the Capital of the territory and the peasant. Its seen that these aspects linked to the "peasant equilibrium" reorient the sugar and alcohol plant insertion, making it difficult or often impossible to these groups have social relationships.
\end{abstract}

Keywords: Peasant agriculture. Sugarcane Agribusiness. Territory. Equilibrium. Frutal (MG).

\title{
Introdução
}

Pensar o campesinato à luz do desenvolvimento e reprodução do capitalismo no campo é algo a que se debruçam diversas áreas das ciências sociais, as quais buscam compreender as lógicas e as metamorfoses de ambos os lados diante dessa relação conflituosa.

De um lado, concepções as quais acreditam na impossibilidade de sobrevivência do camponês dentro de uma unidade produtiva a qual caminha o modo de produção capitalista, tendo sido representada de forma marcante pelos marxistas clássicos, no início do século XX, e de outro, aquelas que apontam para a permanência do campesinato e de atividades ditas "não capitalistas" no cerne de sua acumulação. Isso nos demonstra a diferenciação analítica em relação à concomitância reprodutiva desses dois modelos, bem como a complexidade das disputas territoriais a partir desse embate.

A comunidade Boa Esperança, situada a aproximadamente $30 \mathrm{~km}$ da sede do município de Frutal (MG), passou por grandes mudanças na sua dinâmica territorial a partir da instalação de um grande projeto de investimento para exploração agroindustrial da cana-de-açúcar, a Usina Cerradão Ltda., investimento conjunto entre os grupos Queiroz de Queiroz e Pitangueiras. Foi com a agroindústria que muitos camponeses da 
comunidade foram dificultados ou até mesmo impossibilitados de se manterem em suas propriedades, o que delimitou, em grande medida, suas formas organizativas e suas estratégicas de reprodução social.

Podemos encontrar na região uma diversidade de camponeses que tem na terra seu sustento e sua morada, a terra de trabalho ${ }^{1}$, espalhados em diversas comunidades. Vários deles acabaram sendo diretamente afetados pelo crescimento do número de usinas, porém, em contrapartida, averígua-se intensa resiliência por parte desses agricultores.

Nesse sentido, consideramos aspecto importante do presente estudo o fato de se propor analisar territórios que, em maior ou menor escala, não se inserem na lógica hegemônica do capital, funcionando como verdadeiros "contra-espaços" diante de seu processo de acumulação (HAESBAERT, 2002). A partir desse reconhecimento, podemos buscar modelos de desenvolvimento rural diversificados, e que levem em consideração a pluralidade do campo na região, composto não só pela agricultura moderna capitalista, mas por diversos povos e organizações sociais do Cerrado.

Além disso, a agricultura camponesa, como bem colocou Ianni (2016) se mostra como uma utopia para se pensar uma sociedade futura, diante dos elementos que compõem sua organização, sua dinâmica produtiva e seus modos de vida. A reciprocidade entre todos esses elementos sugere uma forma diferenciada de ações e posturas, a partir de um ponto de vista socialmente equânime e ambientalmente sustentável.

Soma-se a isso a escassa produção acadêmica sobre a reprodução camponesa no município de Frutal (MG). Apesar de encontrarmos trabalhos sobre a territorialização do agronegócio e do setor sucroenergético no município, o campesinato, por vezes, aparece como coadjuvante ou secundário nas pesquisas, o que nos levou a coletar e descrever informações novas e relevantes para o desenvolvimento rural dessa localidade.

Diante dessa complexidade de relações entre o setor agroindustrial, representado pela Usina Cerradão, e os camponeses da comunidade Boa Esperança, o presente artigo tem como objetivo avaliar a conjuntura que possibilitou a nova dinâmica observada na comunidade a partir da noção de "equilíbrios camponeses" proposta por Jan Douwe van der Ploeg, identificando as estratégias estabelecidas por eles diante do embate entre o território do capital e o camponês, o comportamento dos equilíbrios nas unidades pesquisadas, e as adaptações frente a tais disputas.

Para isso, fizemos uma breve análise do contexto a que estão inseridos o município de Frutal e a comunidade Boa Esperança na produção agrícola nacional, bem como as 
novas formas organizativas dos camponeses a partir do ano de 2006, quando foram instaladas as duas usinas sucroenergéticas no município (Usina Frutal - Grupo Bunge, e Usina Cerradão - Grupo Queiroz e Queiroz).

Em um primeiro momento detalhamos a metodologia empregada no trabalho e a caracterização da área de estudo. Posteriormente, apresentamos a discussão sobre a constituição do território camponês e a análise dos equilíbrios camponeses e das novas territorialidades expressas na relação conflituosa entre capital e campesinato na comunidade Boa Esperança/Frutal (MG).

\section{Caminhos metodológicos e caracterização da área de estudo}

A Comunidade Boa Esperança, lócus da pesquisa, conta com um número significativo de camponeses que ainda vivem da terra, apesar das novas estratégias diante da realidade imposta pelas usinas. Tais elementos, assim como a proximidade e influência da Usina Cerradão, distante cerca de $5 \mathrm{~km}$, foram importantes para a delimitação da nossa área de estudo.

Sabe-se que as mudanças na dinâmica agrícola da região, principalmente aquelas voltadas ao agronegócio, levaram a consequências importantes para a comunidade Boa Esperança. Atualmente, o setor responsável por exercer maior influência nesse(s) território(s) é justamente o sucroenergético, aquele que mais cresce e cria dependência econômica no município de Frutal.

Constitui-se então um novo território, o território da agroindústria canavieira. Com ele, novas relações de domínio sobre as forças produtivas e a imposição de novos hábitos, novas identificações, novos sentimentos, novas (i)materialidades (SAQUET, 2007) que demonstram a racionalidade inerente a esse setor.

A comunidade localiza-se no município de Frutal (MG) (Mapa 01), oeste do estado de Minas Gerais, na mesorregião do Triângulo Mineiro. O município abrange uma área de $2.426 .965 \mathrm{~km}^{2}$ e tem uma população estimada de 58.295 habitantes, (IBGE Censo, 2010), possuindo um distrito ${ }^{2}$ (Aparecida de Minas) e oito comunidades $^{3}$ (Água Santa, Boa Esperança, Chatão, Garimpo do Bandeira, Quineira, São Mateus, Serrinha e Vila Barroso), sendo parte da Microrregião de Frutal, a qual abrange doze municípios: Campina Verde, Carneirinho, Comendador Gomes, Fronteira, Frutal, Itapagipe, Iturama, Limeira do Oeste, Pirajuba, Planura, São Francisco de Sales e União de Minas. 


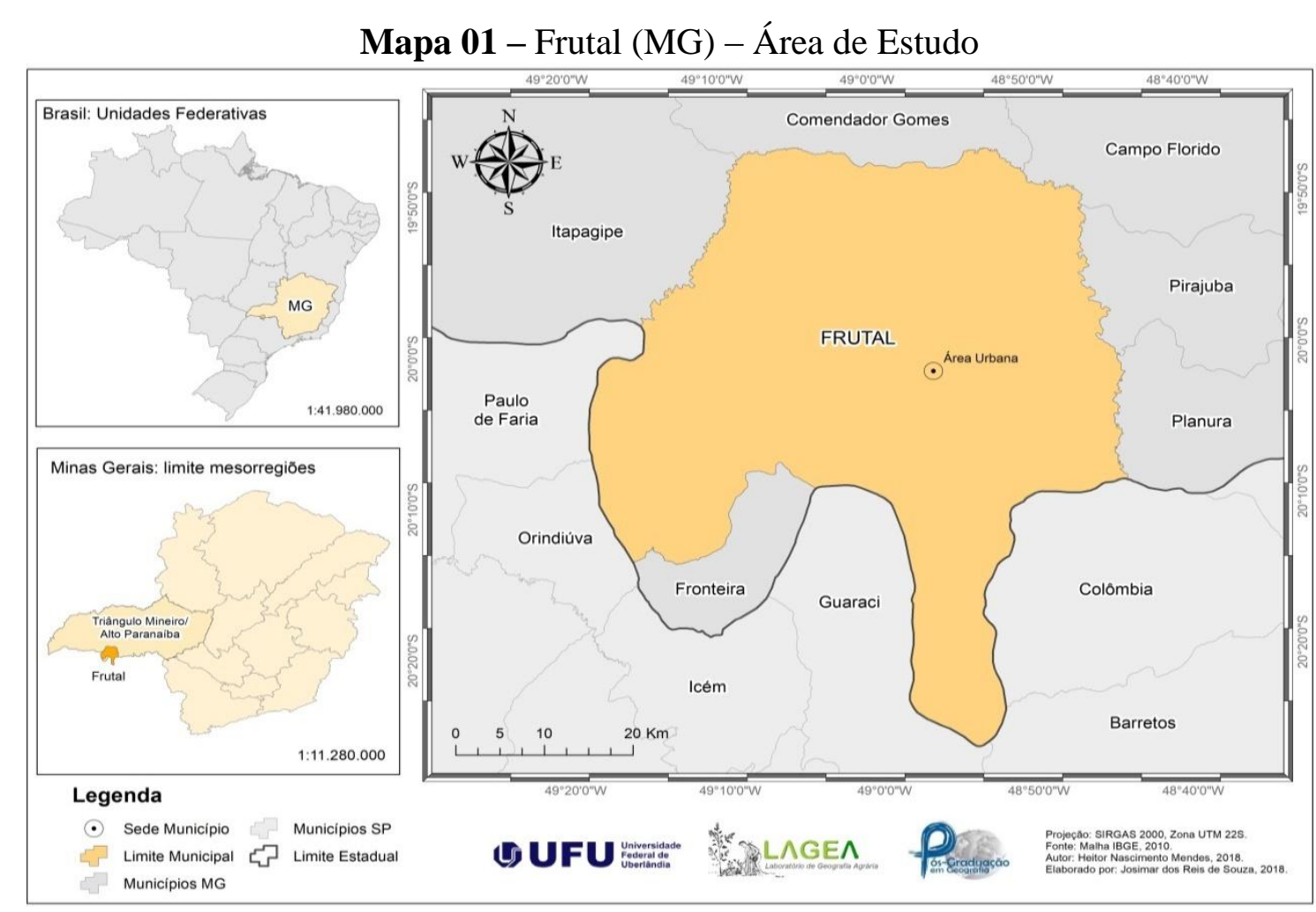

Fonte: Base cartográfica IBGE, 2010.

De acordo com o Censo realizado pelo IBGE (Instituto Brasileiro de Geografia e Estatística) no ano de 2010, cerca de oito mil pessoas seriam contabilizadas como população rural do município em 2016 , pouco mais de $15 \%$ do total, além de ter uma economia voltada principalmente para o setor de serviços e agropecuária, com a indústria exercendo papel menos relevante.

Em relação à agropecuária, a maior parte do Produto Interno Bruto de Frutal provém de grandes produções vinculadas ao agronegócio, como é o caso das monoculturas de laranja, soja, milho e cana-de-açúcar, além da pecuária de gado bovino de corte (SOUZA, 2012).

No entanto, distante dos números que são estabelecidos pelo PIB, há também a existência de uma agricultura em pequena escala que garante a sobrevivência e autonomia de grande parte da população rural do município, seja através do consumo ou da comercialização. Destaca-se nessas propriedades o cultivo de hortaliças, mandioca, frutas como o mamão e banana, suinocultura e pecuária de leite.

As diversas famílias camponesas que hoje vivem na comunidade Boa Esperança estabelecem diferentes estratégias para se organizarem diante da relação conflituosa com o agronegócio e, principalmente com o setor sucroenergético. Localizada a apenas $5 \mathrm{~km}$ de distância da área industrial da Usina Cerradão, os efeitos sobre os territórios são 
facilmente identificados na paisagem, nos modos de vida e nas diversas formas de estabelecerem seus equilíbrios ${ }^{4}$ dentro de cada unidade.

Mapa 02 - Comunidade Boa Esperança e Usina Cerradão Ltda. - Área de estudo

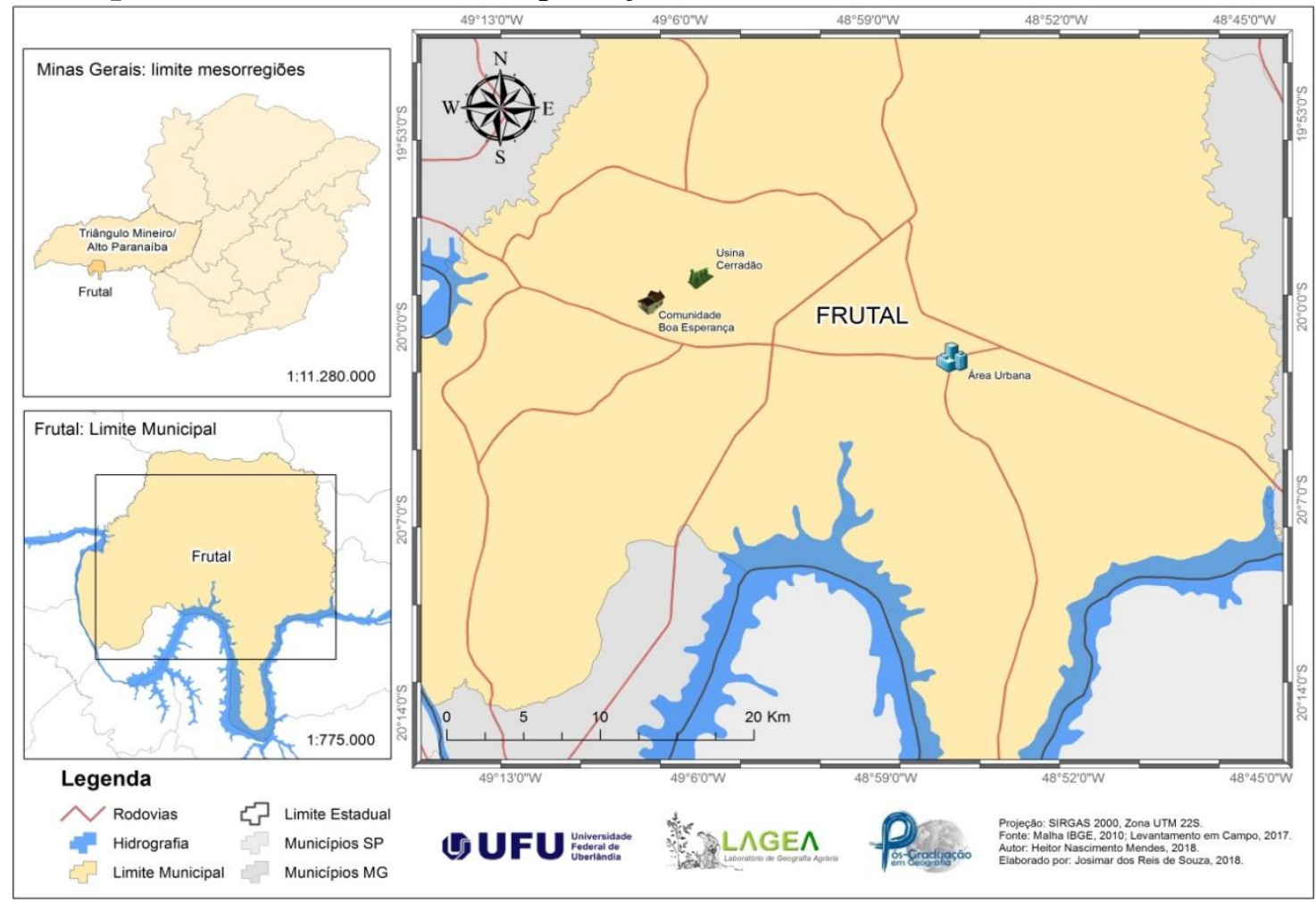

Fonte: Base Cartográfica IBGE, 2010.

Atualmente, as culturas da cana-de-açúcar, laranja, abacaxi e milho figuram como os principais ramos de produção do agronegócio no município (PAM/IBGE, 2016). Dentre elas, o milho e o abacaxi ainda são produzidos (em pequena escala) por diversos camponeses da comunidade. Porém, posterior à chegada das usinas Frutal e Cerradão, ambas no ano de 2006, são cada vez menores as áreas destinadas a essas produções nas suas imediações.

A Usina Cerradão Ltda. é operada pela Agrícola Cerradão, criada e controlada pelas empresas destacadas anteriormente. A materialização do empreendimento iniciouse com a própria constituição da usina no ano de 2006, porém os dois grupos possuíam históricos diferenciados em relação à produção e aos setores de atuação.

O Queiroz de Queiroz Ltda. trilhou sua trajetória a partir da pecuária de corte, sendo um dos maiores produtores de gado bovino com essa finalidade na região. A pouca experiência no plantio da cana-de-açúcar provinha da produção dessa matéria prima para as usinas do Triângulo Mineiro, e foi somente com a consolidação do empreendimento 
em Frutal que o grupo passou a investir acentuadamente no ramo (PESQUISA DE CAMPO, 2017).

O grupo associado (JP Andrade Agropecuária Ltda.) diferentemente do Queiroz de Queiroz, tem seu histórico diretamente vinculado a cana-de-açúcar. Com experiência na produção de aguardente, e posteriormente álcool e açúcar, o grupo seguiu o crescimento das usinas em São Paulo durante as décadas de 1970, 1980 e 1990, chegando ao início da década de 2000 já consolidado e com anseio em adentrar as áreas propícias do Triângulo Mineiro (PESQUISA DE CAMPO, 2017). Tal empresa é um exemplo de como os investimentos no interior de São Paulo foram um propulsor para a chegada das usinas nessa região.

Como estratégia metodológica, foi realizado levantamento bibliográfico em artigos de periódicos, revistas especializadas, documentos, monografias, dissertações, livros, teses e sites fazendo uso de fontes primárias e secundárias, para melhor compreender a realidade local e as especificidades do Triângulo Mineiro e do município de Frutal (MG), principalmente aquelas voltadas à agricultura camponesa e à territorialização do agronegócio e do setor sucroenergético na região.

A análise direta das unidades camponesas foram delimitadas a partir de alguns parâmetros vinculados aos equilíbrios identificados por Ploeg (2016) e a critérios relacionados aos roteiros de entrevistas.

Optamos por pautar nossa análise das unidades camponesas e da sua relação com a agroindústria canavieira na comunidade Boa Esperança, a partir do nível micro, pois entendemos que a individualidade de cada unidade, bem como as relações entre elas, expressam de forma satisfatória e orgânica os processos e condições macro, além de serem o núcleo reprodutivo, de luta e das mudanças relativas ao campesinato.

Nesse sentido, a análise das unidades funcionaria, de acordo com Ploeg (2016), como um filtro para identificarmos e interpretarmos tais condições econômicas e sociais dos territórios camponeses, onde os efeitos macro de fato acontecem e são estabelecidos. Portanto, o nível micro seria

[...] o lugar onde as tendências, previsões, relações de preço, mudanças nas políticas agrárias ou qualquer outra causa macro são ativamente interpretadas e transformadas pelos agricultores (e outros sujeitos) em atitude, criando assim os efeitos macro que de fato ocorrem. É como um processo de filtragem, com estímulos (preços, políticas etc.) do nível macro sendo sempre mediados por e por meio dos sujeitos agindo no nível micro. Sem compreender a lógica desses sujeitos não é possível entender ou prever os efeitos ou resultados desses estímulos macro. (PLOEG, 2016, p. 29-30). 
Os equilíbrios compilados por Ploeg (2016) são um avanço daqueles identificados e trabalhados por Chayanov (1974) no início do século XX. Para este autor, existiriam dois equilíbrios básicos das unidades camponesas ora analisadas: o equilíbrio trabalhoconsumo, voltado para as relações de demanda de consumo e da força de trabalho existente na esfera familiar, e o equilíbrio utilidade-penosidade, relacionado aos esforços para aumentar a produção e, por consequência, a renda familiar (utilidade), e as adversidades inerentes ao processo de trabalho (penosidade).

Quadro 01 - Equilíbrios e parâmetros de avaliação das unidades camponesas

\begin{tabular}{|c|c|}
\hline Equilíbrio & Parâmetros de avaliação \\
\hline Trabalho-consumo & $\begin{array}{l}\text { Esfera familiar; Relação entre as demandas de consumo da família e } \\
\text { a força de trabalho existente dentro da mesma; Produção total e } \\
\text { consumo para suprir todas as necessidades da família; }\end{array}$ \\
\hline Utilidade e penosidade & $\begin{array}{l}\text { Esfera do trabalhador individual; Utilidade como esforços extras } \\
\text { necessários para aumentar a produção total (renda total) e penosidade } \\
\text { associada às adversidades (longas jornadas de trabalho, trabalhar sob } \\
\text { condições extremas etc.); Natureza agradável ou extenuante do } \\
\text { trabalho rural; Relações com o crescimento da produção (útil ou } \\
\text { penoso?) }\end{array}$ \\
\hline Pessoas e natureza & $\begin{array}{l}\text { Conexão entre agricultura e ecologia; Coprodução entre o social e o } \\
\text { natural; Pessoas e natureza combinadas na prática da agricultura; } \\
\text { Interações e transformações contínuas; maleabilidade dos recursos } \\
\text { naturais e desenvolvimento de uma agricultura endógena; } \\
\text { coprodução realçando as habilidades; reconhecimento dos domínios } \\
\text { social e natural. }\end{array}$ \\
\hline Produção e reprodução & $\begin{array}{l}\text { Recursos internos; Constante reprodução dos recursos utilizados; } \\
\text { Renovação de capital e menor dispêndio de energia. }\end{array}$ \\
\hline Recursos internos e externos & $\begin{array}{l}\text { Recursos externos; Escolha entre "fazer" e "comprar"; Maior ou } \\
\text { menor dependência do mercado; Grau de mercantilização; Grau em } \\
\text { que a propriedade está conectada ao mercado; Relação entre recursos } \\
\text { (internos ou externos) e penosidade. }\end{array}$ \\
\hline Autonomia e dependência & $\begin{array}{l}\text { Instituições sociais que cercam a produção e distribuição de riqueza; } \\
\text { Relações de classe e mecanismos de extração de excedente; Luta por } \\
\text { autonomia dentro de um contexto que imponha dependência e } \\
\text { privação. }\end{array}$ \\
\hline Escala e intensidade & $\begin{array}{l}\text { Número de objetos de trabalho (unidades de terras, animais etc.) e } \\
\text { produção por objeto de trabalho; Heterogeneidade; Estilos de } \\
\text { agricultura. }\end{array}$ \\
\hline
\end{tabular}

Para além desses dois equilíbrios, Ploeg (2016) identifica outros cinco, abrindo espaço para uma análise mais abrangente, visto que abarca diferentes esferas da vida dos camponeses e de suas relações com a produção, com os recursos, com a natureza dentre outros, além de ser uma opção metodológica para a análise das especificidades dos territórios camponeses em diversas partes do globo. 
Como se pode observar no quadro 01, há equilíbrios relativos ao próprio núcleo familiar, ao seu prolongamento (para que se produz, de onde provém os recursos, grau de dependência dentre outros), bem como nas interferências dos processos que ocorrem "fora" da propriedade, e que podem (re)organizar a unidade e a reprodução da família (relação com a natureza, reciprocidade, impactos ambientais). É importante atentarmos para interdependência de todos os equilíbrios, que para fins de análise serão trabalhados separadamente.

Nas entrevistas, buscamos abarcar questões pertinentes aos equilíbrios, assim como nas técnicas utilizadas na pesquisa de campo (diário de campo e história oral) e em toda observação direta das unidades camponesas, visto que alguns desses equilíbrios podem ser subjetivos e estarem vinculados à dinâmica interna de cada unidade, além da heterogeneidade e da gama de possibilidades em relação a eles. Nesse sentido, buscou-se compreender melhor indicadores como: (a) formas de obtenção da terra, (b) alocação do trabalho familiar, (c) tempo na comunidade, (d) utilização da terra, (e) autonomia, (f) serviços oferecidos, (g) perspectivas de permanência na comunidade, (h) manutenção das tradições, dentre outros.

Quadro 02 - Variáveis do roteiro estruturado abarcando diversos fatores acerca da propriedade, família e equilíbrios das unidades camponesas.

\begin{tabular}{|c|c|}
\hline Fatores & Parâmetros de avaliação \\
\hline Camponês e propriedade & $\begin{array}{l}\text { Composição familiar; onde residem; onde trabalham; forma de } \\
\text { aquisição da propriedade; tamanho da propriedade; tempo na } \\
\text { comunidade; formas de renda. }\end{array}$ \\
\hline Produção & $\begin{array}{l}\text { Produtos cultivados; produtos para autoconsumo e comercializados; } \\
\text { redes de comercialização; quantidade produzida; renda aproximada. }\end{array}$ \\
\hline Comercialização de produtos & $\begin{array}{l}\text { Compra dos produtos; rotina de comercialização; valores alcançados; } \\
\text { meios de transporte; acesso à informação; problemas com a } \\
\text { comercialização. }\end{array}$ \\
\hline Força de trabalho & $\begin{array}{l}\text { Tipos de mão-de-obra; diferentes atividades produtivas e força de } \\
\text { trabalho; trabalho assalariado; venda da força de trabalho. }\end{array}$ \\
\hline Associativismo & Relação com vizinhos; conflitos; auto-denominação; mutirões. \\
\hline Organização política & $\begin{array}{l}\text { Membro de associação, sindicato ou cooperativa; participação em } \\
\text { movimentos sociais; }\end{array}$ \\
\hline Aspectos culturais & $\begin{array}{l}\text { Eventos culturais; manutenção de festas tradicionais; sentido das } \\
\text { atividades; relações comunitárias. }\end{array}$ \\
\hline Chegada da Usina & $\begin{array}{l}\text { Atividades de lazer; religiosidade; mudanças a partir da chegada da } \\
\text { usina; serviços oferecidos pela usina; venda de força de trabalho para } \\
\text { a usina; permanência na comunidade. }\end{array}$ \\
\hline Fatores & Parâmetros de avaliação \\
\hline Agroindústria & $\begin{array}{l}\text { Opinião sobre a chegada da usina (benefícios, dificuldades); influência } \\
\text { da área de cultivo da cana-de-açúcar; qualidade ambiental; utilização } \\
\text { das terras pela usina (compra e arrendamentos). }\end{array}$ \\
\hline
\end{tabular}

Org.: Autor (2017). 
Além da entrevista, as outras técnicas utilizadas foram muito importantes durante todo o decorrer da pesquisa de campo. A história oral, denominada também de história de vida ou relato de vida, é um instrumento importante na obtenção de dados e informações acerca da realidade estudada, pois os aspectos culturais podem se refletir nas falas e ações dos sujeitos.

Essa técnica é bastante utilizada para remontarmos aspectos históricos os quais são resgatados na memória de pessoas que tiveram uma ligação histórica com a realidade a ser compreendida. "A história oral possibilita o registro de coisas que se fixaram na memória das pessoas, reinterpretando o passado e/ou revelando fatos desconhecidos" (MARCONI; LAKATOS, 2007, p.40).

\section{Os equilíbrios da unidade camponesa enquanto estratégia de reprodução social na comunidade Boa Esperança/Frutal (MG)}

Ao analisarmos a atual conjuntura da produção agrícola na comunidade Boa Esperança, notamos que as tendências averiguadas no início do século se confirmaram em diversos aspectos. Com o setor sucroenergético crescendo vertiginosamente, e a posterior instalação da Usina Cerradão no ano de 2006, presenciamos uma severa mudança no panorama da produção agrícola da comunidade, tanto aquela vinculada ao agronegócio, como também nas propriedades camponesas.

Em relação ao município de Frutal, das produções voltadas ao agronegócio, a sucroenergética foi a que mais cresceu e hoje domina os índices da produção de commodities. Ao compararmos os números dos últimos anos (2012-2016), observaremos o crescimento da produção e da área de abrangência das lavouras de cana-de-açúcar em relação às outras culturas.

A tabela 01 mostra como no ano posterior a instalação das usinas em Frutal (2007), o cultivo da cana-de-açúcar já apresentava números elevados, porém a soja ainda ocupava maior área.

Tabela 01: Frutal (MG) - Produção Agrícola, 2007

\begin{tabular}{lcc}
\hline \multicolumn{1}{c}{ Culturas agrícolas } & Área colhida (ha) & Quantidade produzida \\
\hline Abacaxi & 1600 & $48000(1000$ frutos $)$ \\
Cana-de-açúcar & 10128 & $810240(\mathrm{t})$ \\
Laranja & 6500 & $130000(\mathrm{t})$ \\
Milho & 5500 & $33000(\mathrm{t})$ \\
Soja & 26000 & $78000(\mathrm{t})$ \\
\hline
\end{tabular}

Fonte: Produção Agrícola Municipal (PAM), 2007.

Org.: Autor, 2018 
Nesse ano (2007), a área cultivada de cana-de-açúcar no município já ultrapassava os 10.000 hectares, produzindo cerca de 810 mil toneladas (PAM/IBGE, 2007). Nesse momento as duas usinas ainda não haviam entrado em operação, porém o processo de obtenção de terras (compra e arrendamento) e implantação da infraestrutura necessária à suas operações já se iniciara. O cultivo era feito majoritariamente pelas usinas dos municípios limítrofes e por produtores que a revendiam em tais unidades, como é o caso do grupo Queiroz de Queiroz em Frutal.

Observa-se no mapa 03 que, no ano de 2007, as lavouras de cana-de-açúcar ocupavam majoritariamente a porção sudoeste do município, a partir dos municípios de Fronteira (MG) e Orindiúva (SP), e nordeste, a partir de Pirajuba e Campo Florido, ambos em Minas Gerais. Todos eles já contavam com a presença de uma usina, operando já há alguns anos.

Em Campo Florido, as operações da Usina Cururipe se iniciaram em 2002, sendo, portanto um empreendimento já consolidado e com expansão na obtenção de terras para além dos limites do município. Caso parecido ocorria com a Destilaria Rio Grande S.A., em Fronteira, que já operava desde o ano de 2007 (PESQUISA DE CAMPO, 2017).

Mapa 03 - Frutal (MG) - Áreas ocupadas com lavoura de cana-de-açúcar, safra $2006 / 2007$

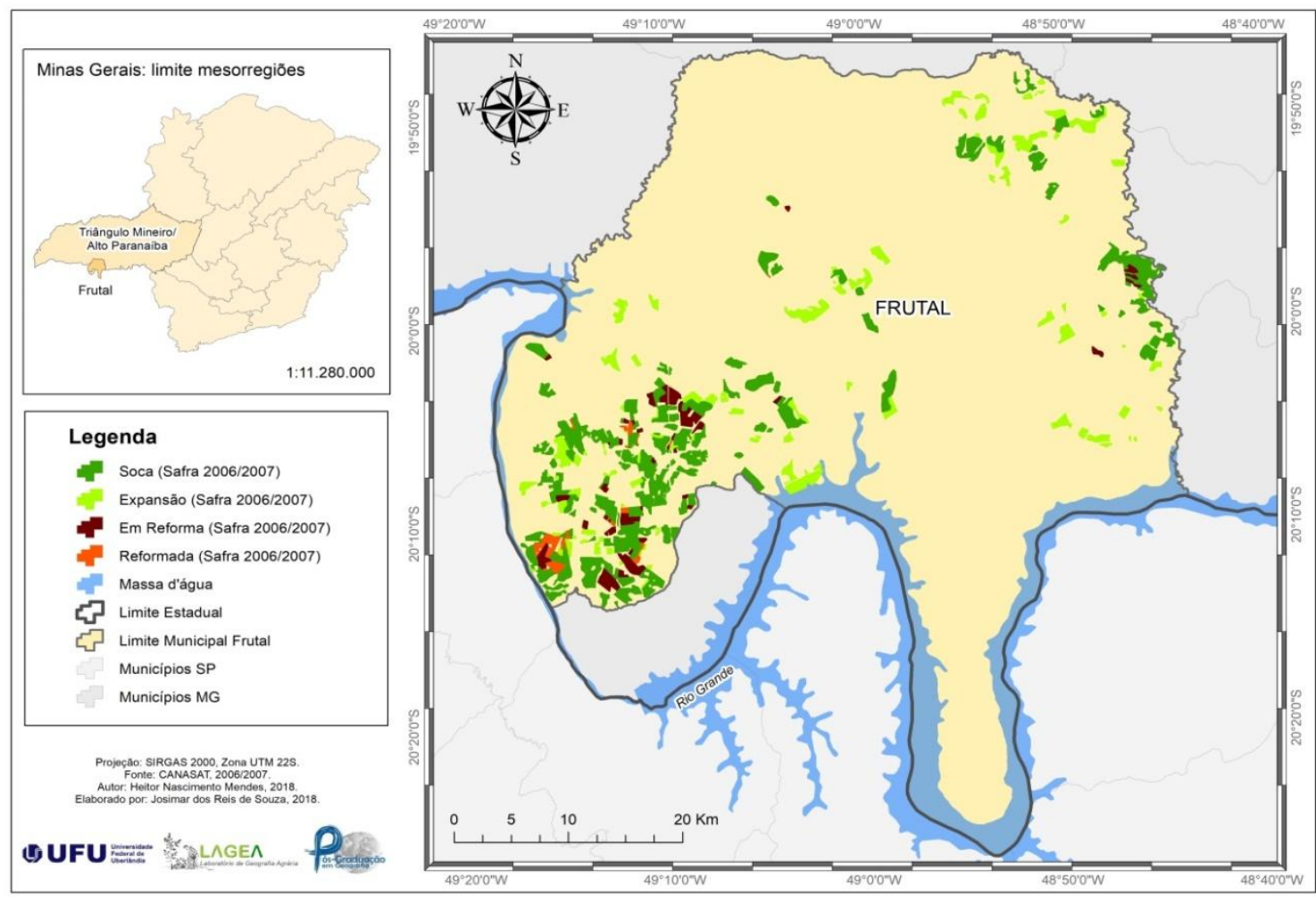

Fonte: Base cartográfica IBGE, 2010. 
Nota-se que as áreas em expansão das lavouras já representam parte significativa do total, porém nenhuma delas se encontra na porção noroeste do município, local onde está instalada a Usina Cerradão (mapa 02) e onde poderemos observar grande aumento nos anos seguintes. As áreas em reforma e reformada denotam áreas utilizadas há certo tempo para essa finalidade.

Na safra 2009/2010, primeiro ano de operação efetiva da usina, a área colhida já havia triplicado, chegando aos 30 mil hectares, produzindo pouco mais de 2,5 milhões de toneladas (PAM/IBGE, 2010). Nesse momento se consolidava o processo de territorialização das duas usinas do município, ambas em operação desde 2009.

Nos anos seguintes o crescimento da produção de cana-de-açúcar e de sua produtividade foi vertiginoso. Na safra 2013/2014 a área colhida chegou a 62.140 hectares, e a quantidade produzida atingiu a marca de 5.084.800 toneladas (PAM/IBGE 2014). No mapa 04 podemos notar a expansão das áreas em relação ao período de instalação das usinas.

Mapa 04 - Frutal (MG) - Áreas ocupadas com lavoura de cana-de-açúcar, safra $2012 / 2013$

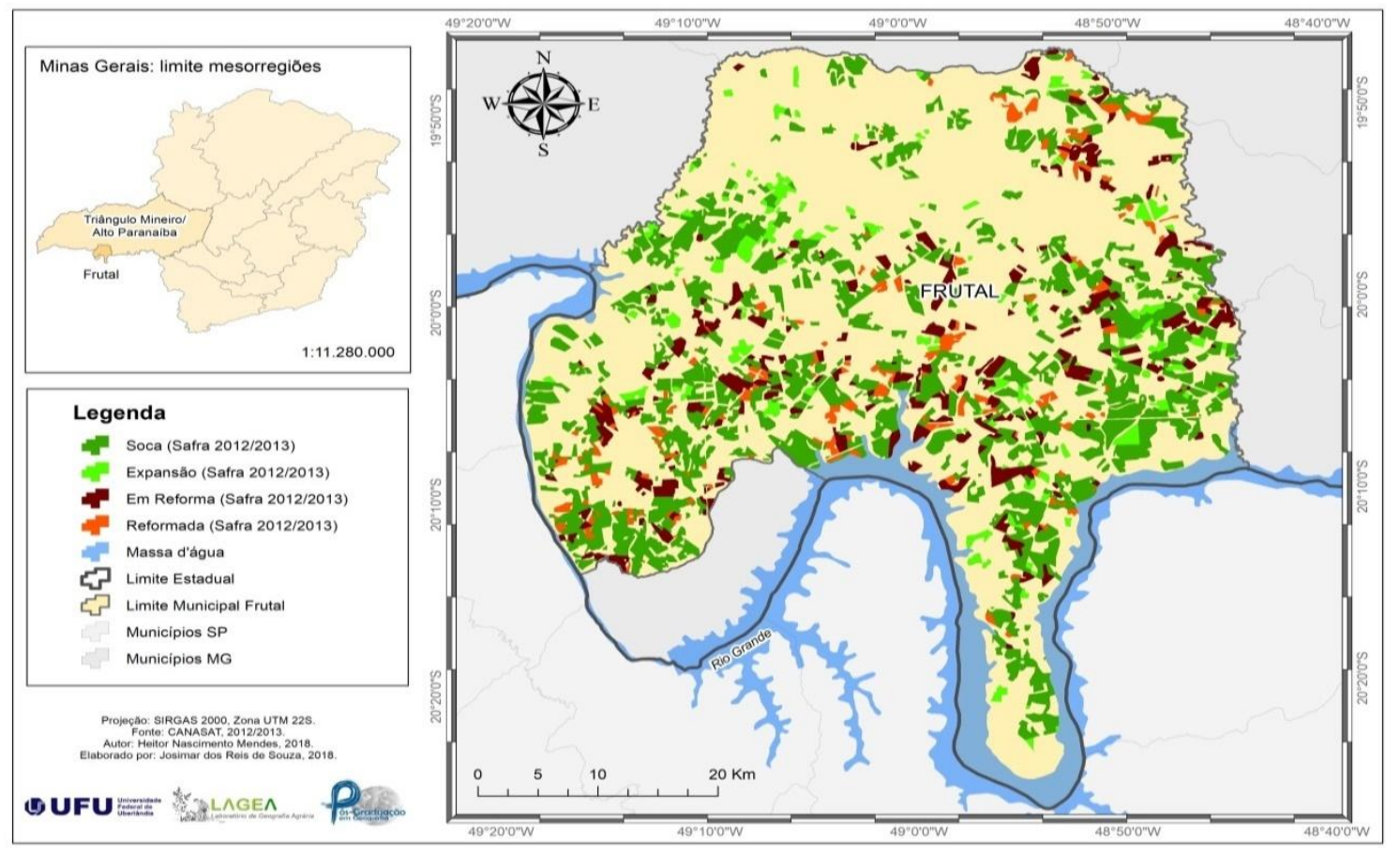

Fonte: Base cartográfica IBGE, 2014.

A porção noroeste, onde se encontra a Usina Cerradão (mapa 02) apresenta áreas apenas em soca e em expansão, o que aponta para lavouras relativamente recentes, visto 
que um único plantio permite até seis colheitas consecutivas sem a necessidade de reforma, a depender de diversos fatores como clima, manejo ou disponibilidade hídrica.

As áreas onde se encontram as usinas (noroeste e sudeste do município) apresentam crescimento nas lavouras, o que denota a utilização dessas terras pelo próprio empreendimento, algo que não estava presente na safra 2006/2007 (Mapa 03). Como será observado, essa situação é extremamente relevante para as estratégias do campesinato e do trabalho conjunto com o meio ambiente natural que lhe é inerente, assim como das diversas populações tradicionais do Cerrado.

Foi por conta de um desses fatores naturais que a produção sucroenergética da região passou por uma crise durante as safras 2014/2015 e 2015/2016. Essa situação afetou não só as usinas do Triângulo Mineiro, mas também de diversas regiões do país, e está relacionada, entre outros motivos, ao longo período de estiagem e a diminuição da moagem na safra 2013/2014, além das alterações no preço do etanol no mercado internacional (PESQUISA DE CAMPO, 2017).

Nesse sentido, observamos na tabela 02 como a produção no município veio aumentando até esse momento, sofrendo leve queda nos anos posteriores (2014-2016). Porém, esse processo não foi representativo para a comunidade e para os camponeses, e longe de ser perceptível diante das mudanças já sentidas pelo avanço das lavouras e da territorialização da usina.

A contínua obtenção de terras e a consolidação do setor no município levaram a uma conjuntura que pouco mudou durante os anos de crise. Podemos falar, em realidade, ao agravamento da condição do camponês mesmo nesse período.

Tabela 02 - Frutal (MG) - Cana-de-açúcar - Área colhida e quantidade produzida 2010-2016

\begin{tabular}{ccc}
\hline Ano & Área colhida (ha) & Quantidade Produzida (t) \\
\hline 2010 & 30689 & 2455120 \\
2011 & 30689 & 2455120 \\
2012 & 49000 & 3825000 \\
2013 & 57000 & 3897000 \\
2014 & 62140 & 5084800 \\
2015 & 61972 & 5001040 \\
2016 & 61972 & 5001040 \\
\hline
\end{tabular}

Fonte: Produção Agrícola Municipal (PAM), 2018.

Org.: Autor, 2018.

Como vimos, o cenário aponta para uma situação totalmente nova para os camponeses da comunidade Boa Esperança. Diante das características do 
desenvolvimento do agronegócio no município de Frutal, que até a década de 1990 apresentava certa diversidade produtiva e abarcava, até certo ponto, o pequeno produtor, observamos uma (re)organização territorial que delimita de forma ainda mais marcante a sua reprodução social.

Nesse sentido, as estratégias são constantemente renovadas dentro de cada unidade camponesa, paralelamente a uma "uniformização" do campo a partir das lavouras de cana. A adaptação se faz necessária e o repertório se apresenta como diverso, com retomadas de certas estratégias, bem como a incorporação de novos elementos na produção, na cultura e em toda a organização comunitária.

A partir da operação da usina, uma série de arrendamentos, compras e impactos diretos e indiretos do cultivo da cana passaram a ser identificados nas propriedades, e a relação do campesinato com o agronegócio toma outros contornos. Especificamente em relação à comunidade Boa Esperança, sua proximidade com a usina a faz ocupar lugar de destaque quando analisamos a interferência da produção canavieira nos territórios camponeses.

É muito perigoso morar ali. Olha, se aquela cana pega fogo eu não sei o que vai ser daquelas casas. Tá tudo cercado. Tem cana no quintal das casas. Se vem fogo com vento é perigoso não dá tempo nem de correr. E os aviões? Nossa, tinha dia que eu achava que ele ia cair na minha cabeça. Chegava a correr pra dentro de casa com medo. (ENTREVISTA 01, Agosto de 2017).

A angústia relatada pelo entrevistado, já residente na cidade de Frutal (MG), mostra a realidade vivenciada hoje por grande parte dos camponeses que ainda vivem nas redondezas da Usina Cerradão. A camponesa em questão relata que dava a vida pela comunidade Boa Esperança, que tinha grande apreço em realizar as festas, em ajudar os que necessitavam, enfim, em manter o espírito comunitário entre eles. As dificuldades em se manter ali aumentaram com os problemas de saúde do marido e o avanço da cana em seu quintal, a qual a impossibilitou de produzir seus alimentos.

\footnotetext{
$\mathrm{O}$ veneno mata tudo. Nada mais deu depois que começaram a passar aqui em cima. Os mamões nem crescem e já estão maduros, e se demorar muito apodrecem. As couves, o alface, tudo perdia alguns dias depois que o avião passava. Ai não dava pra ficar. O marido ficou doente, não tinha médico lá pra gente correr se precisasse, ai viemos embora. Mas eu ainda volto! Ô se volto! (ENTREVISTA 01, Agosto de 2017).
}

Os relatos voltados ao Ethrel ${ }^{5}$ são vários. Na Escola Municipal Odílio Fernandes ${ }^{6}$, em uma única vez que a aeronave sobrevoou a comunidade sem desligar o jato de veneno, foi perdido mais de 800 pés de alface, em uma horta que abastece grande parte da comunidade. $\mathrm{O}$ movimento na horta demonstra o aspecto comunitário ainda presente, $\mathrm{o}$ 
que, de acordo com o zelador, "é pra todo mundo", e todos os dias muitas pessoas passam para pegar seu pé de couve, repolho, alface e temperos.

A usina Cerradão ocupa uma área agrícola cada vez maior desde sua instalação, no ano de 2006. De acordo com informações colhidas em campo, a perspectiva para os próximos três anos é de que praticamente se duplique tal área. Diversas propriedades estão passando pela mesma situação observada acima, o que dificulta e muitas vezes impossibilita, como ocorreu neste caso, a permanência na comunidade.

De acordo com os dados da pesquisa de campo, aproximadamente 70.000 ha são utilizados para essa cultura atualmente pela usina, entre terras compradas e arrendadas. Para o Gerente de produção Agrícola (Entrevista 04), sobram terras e mão-de-obra na região, seja para arrendamentos ou para compra, algo que, portanto, não será um obstáculo para o avanço em outras propriedades.

A quantidade de maquinários utilizados na produção também mudou o cotidiano da comunidade. No período seco, a poeira toma conta do ambiente, e a mínima quantidade de vegetação nativa agrava o problema, visto que o microclima na área é transformado, e as temperaturas, nitidamente, são maiores dentro do canavial.

Além do aspecto físico, os trabalhadores que constituem a mão-de-obra não especializada da usina, como no caso dos motoristas e safristas, em sua maioria são migrantes, o que transforma a percepção e a identificação dos moradores com a comunidade, visto que tais trabalhadores não estabelecem forte vínculo com a comunidade. A região acaba se tornando um local de passagem para grande parte deles, e os laços comunitários se dificultam.

Em um ensaio sobre as relações entre os "estabelecidos e os outsiders", ou os "de dentro e os de fora”, Elias e Scotson (2000) demonstram como é delicado esse contato, cercado muitas vezes de pré-conceitos e relações identitárias que dificultam a aproximação entre os dois grupos. De acordo com ele, podemos observar

[...] uma clara divisão, em seu interior, entre um grupo estabelecido desde longa data e um grupo mais novo de residentes, cujos moradores eram tratados pelo primeiro como outsiders. O grupo estabelecido cerrava fileiras contra eles e os estigmatizava, de maneira geral, como pessoas de menor valor humano. Considerava-se que lhes faltava a virtude humana superior o carisma grupal distintivo - que o grupo dominante atribuía a si mesmo. (ELIAS; SCOTSON, 2000, p. 19).

É claro que os referidos autores estão mostrando uma realidade fictícia para dar conta de sua explicação sociológica sobre a territorialização de novos grupos sociais, porém, assim como constatado por eles, podemos observar relações de não reciprocidade 
entre os grupos relacionados ao território da comunidade e da usina. Esse embate por vezes compromete a própria ressignificação da comunidade, visto que muitos a veem hoje como um lugar perigoso, cheio de máquinas, de veneno, enfim, transformada pelo aspecto material e simbólico incorporados pela agroindústria.

Em contraponto a esse processo, em meados de 2017 pudemos fazer parte de uma das principais festividades da comunidade: a festa de "São João", realizada no mês de agosto no pátio da Escola Municipal Odílio Fernandes, para que fosse comemorada juntamente com o início do semestre escolar. Como constatado pela diretora, "os recursos estão escassos, mas não queremos deixar de realizar as festas. A burocracia também está dificultando a realização delas, mas ainda buscamos fazer, pelos alunos e pela comunidade" (Entrevista 03, agosto de 2017).

A partir dessa e de outras comemorações, conseguimos identificar laços ainda fortes dos camponeses com a comunidade. A realização de terços, principalmente no natal (25 de dezembro) e no feriado católico de Nossa Senhora Aparecida (12 de outubro), e as festas na escola dão sinal de que a comunidade resiste, mesmo com as dificuldades descritas por eles.

Porém, apesar desses esforços, as festividades, quermesses, mutirões, torneios de futebol, os quais faziam parte da apropriação simbólica e material desse espaço, praticamente deixaram de existir nos últimos anos, de acordo com os relatos colhidos nas entrevistas. Observa-se que o território camponês, vinculado à comunidade pelas tradições mantidas há décadas, está perdendo suas bases diante dos conflitos e da territorlização do capital agroindustrial.

Ao adentramos as propriedades camponesas, começamos a acessar informações importantes às quais nos apontaram para uma permanência e certo ressurgimento de estratégias reprodutivas as quais, nos primeiros anos da década de 2000, dados oficiais e as próprias entrevistas apontaram o contrário.

Em relação às culturas agrícolas, as plantações de milho e abacaxi estão presentes em várias das propriedades, algo ressaltado na entrevista 08. Uma das possibilidades encontradas por eles é justamente a tentativa de diversificar a produção, buscando novas oportunidades de renda e uma "fuga" daquelas culturas impactadas pelos métodos de plantio da cana, como algumas frutas e a pecuária de leite.

Sobre o abandono de certas culturas e o investimento em outras, nos foi relatado em várias das entrevistas a impossibilidade de produzi-las em razão da intensa 
pulverização aérea na cana-de-açúcar. A produção do mamão está inviabilizada atualmente em razão desse processo, visto que os reguladores de crescimento e maturação da cana, aplicados na lavoura através desse processo, invadem a propriedade e afetam a produção, fazendo acelerar o amadurecimento das frutas mesmo elas não estando prontos para a colheita.

Outra produção bastante relevante para as propriedades camponesas da comunidade é a mandioca. Cerca de $70 \%$ dos entrevistados citaram essa produção como fonte de renda extra da família, porém alguns deles apontaram o cultivo do tubérculo como extremamente relevante diante das dificuldades enfrentadas pela pecuária de leite. Dentre os fatores que agravam essa situação estão o preço do litro de leite nas cooperativas, que não passa de 90 centavos (em 2017), e principalmente a chamada "mosca-do-estábulo", que se reproduz a partir da vinhaça ${ }^{7}$. O inseto impossibilita o gado de se alimentar em razão das picadas frequentes, causando diversas lesões, diminuição da produção de leite e até a morte do animal.

Nesse sentido, alternativas em relação à produção de leite são cada vez mais frequentes nas propriedades, visto que a situação se agrava. A Usina Cerradão Ltda. se compromete, em razão das diversas reclamações dos agricultores, a pulverizar as áreas afetadas, porém, a demora e as promessas não cumpridas os fazem desacreditar em tais compromissos (DIÁRIO DE CAMPO, 2018).

A mandioca, assim como o abacaxi e o milho, é comercializada majoritariamente na rede urbana, nos municípios de Frutal (MG) e Itapagipe (MG), este último distante cerca de $10 \mathrm{~km}$ da comunidade. A produção de mandioca, como relatado por um camponês da comunidade, é plantada entremeada com a vegetação, a qual serve como matéria orgânica e para melhoria na qualidade do produto. Além dessa produção, a propriedade em questão produz leite e alguns derivados (vendidos também na rede urbana), e o camponês tinha como renda extra o transporte escolar, realizado através de uma Kombi de propriedade da família.

Diante dessa conjuntura, discutiremos a seguir os equilíbrios relativos à reprodução social e econômica daqueles camponeses que "viveram da terra" durante todo o período de avanço da cana-de-açúcar na comunidade (2006-2018), conforme estabelecidos por Ploeg (2016), atentando para o aspecto histórico do agronegócio na região, bem como da comunidade e da sua relação com a produção das commodities. 
Consideramos que a busca do camponês por relativa autonomia em relação ao agronegócio canavieiro e, até certo ponto, ao Estado, se dá através das formas organizativas de suas propriedades. A partir do nível micro, procuramos traçar um panorama das potencialidades e das imposições a que estão sujeitos, bem como os elementos que os aproximem ou distanciem em seus multiterritórios.

\section{O equilíbrio trabalho-consumo nas unidades camponesas}

A força de trabalho das propriedades analisadas é composta basicamente pelo casal camponês e seus filhos. Porém, algumas transformações estão ameaçando a reprodução dessa configuração e da própria família.

Em busca de estudos ou a trabalho, um grande número de famílias desprendem parte de sua renda para a formação dos filhos, na busca por certa estabilidade e fuga das mazelas ali enfrentadas. Para essa parcela, o êxodo das novas gerações é um processo natural.

Em contrapartida, a maioria das famílias ainda conta com ao menos um filho vivendo na propriedade, já mais velhos. A força de trabalho é maior e a possibilidade de manutenção da propriedade de forma produtiva se mostra mais evidente em razão dessa permanência.

Além de contarem com os filhos na agricultura e na atividade doméstica, há também a busca por renda extra nos pequenos comércios da comunidade ou nas propriedades vizinhas. Na pesquisa de campo, encontramos o exemplo de um camponês que cuida sozinho da propriedade, porém consegue manter um pequeno restaurante na comunidade, o qual é conduzido pela filha mais velha, que trabalhou por um tempo na usina, mas acabou voltando para o trabalho familiar.

Outro exemplo está em outra família campoensa. Nesse caso, o filho trabalha na ordenha leiteira de uma propriedade vizinha, não fazendo assim os trabalhos referentes à propriedade da família. Esse processo auxilia numa maior possibilidade de renda e consequente diminuição da penosidade do trabalho por parte do camponês, como será demonstrado nos subitens seguintes.

Em mais de $70 \%$ das propriedades ao menos um filho é trabalhador rural (na própria unidade ou em fazendas vizinhas). Aqueles que têm filhos com curso superior e vivendo na cidade (46\%) ou que lá trabalham (20\%) passaram por mudanças significativas recentes em relação a esse equilíbrio, bem como aqueles que dão preferência aos filhos estudarem. 
A troca de favores relativa a determinado serviço prestado é utilizado em $26 \%$ das propriedades analisadas, porém, isso ocorre em momentos específicos, principalmente na colheita das lavouras. Essa troca é feita principalmente nas propriedades onde apenas o camponês representa a força de trabalho (como os viúvos e os que não contam com filhos para auxiliá-los). Dentre as trocas estabelecidas estão a moradia, o fornecimento de produtos alimentícios produzidos na propriedade, e em outros momentos alguma ajuda financeira, mas que não podemos considerar assalariados pois são raras as circunstâncias em que ocorrem e funcionam como um beneficiamento extra, e não pagamento direto pelos serviços prestados.

Como o grau de escolaridade dos camponeses é baixo, o trabalho na usina ficou inviável, apesar das promessas de emprego da mesma. Aqueles que ali trabalharam ou trabalham ocupam funções com menores níveis de especialização. Os camponeses mais novos apresentam níveis mais altos de escolaridade, os mais velhos em sua maioria estudaram até o Fundamental I.

Em 53\% das propriedades encontramos camponeses (tanto o homem como a mulher) que tem algum outro tipo de renda suplementar, principalmente aqueles que possuem algum tipo de maquinário ou transporte próprio. Nesses casos se destacam os serviços prestados com trator e maquinários e a mão-de-obra em propriedades vizinhas, e o transporte escolar. O trabalho nas safras da cana e as vendas são outros exemplos dessa suplementação.

De acordo com relatos colhidos nas entrevistas, a necessidade de trabalho extra fora da propriedade se mostra cada vez mais necessário em razão das dificuldades enfrentadas na produção de leite. Como vimos, a criação de gado de leite é a base da grande maioria das propriedades analisadas, e os impactos relacionados à "mosca-doestábulo", bem como do baixo preço do leite, estão levando uma série de camponeses a adaptarem sua produção e/ou buscarem renda auxiliar fora da propriedade.

A divisão de trabalho por sexo se faz presente na totalidade das unidades analisadas, e na maioria delas as mulheres (e as filhas) se ocupam das atividades domésticas, e o homem (e os filhos) da agricultura e de toda a estrutura da propriedade. De forma menos marcante temos algumas camponesas trabalhando em algumas atividades na escola e no posto de saúde da comunidade.

As aptidões de cada membro da família, bem como suas necessidades de lazer e estudo são relevantes para o trabalho empreendido. As dificuldades são balanceadas para 
que o trabalho e o consumo sejam equilibrados dentro das especificidades da família, como o tempo passado na escola (por parte dos filhos) e as atividades recreativas e de lazer.

Esse cenário se conforma, em grande medida, em razão da preferência dos pais aos estudos dos filhos. $\mathrm{Na}$ maioria das propriedades encontramos camponeses determinados para que façam curso superior, apesar das dificuldades futuras em manterem a propriedade. As imposições levam a família a repensar as opções oferecidas para os filhos, como o de seguirem no campo ou estudarem e se especializarem na cidade, fugindo assim da vida difícil que se encontram.

As necessidades de trabalho e consumo dentro da propriedade, portanto, são balanceadas em razão da disponibilidade de força de trabalho dentro da propriedade, de como ela é dividida e da necessidade de consumo da família, que por sua vez se vinculam às imposições dos processos ocorrentes no contexto que se inserem.

\section{O equilíbrio utilidade-penosidade nas unidades camponesas}

O grau de utilidade e penosidade dos camponeses se relacionam diretamente ao equilíbrio discutido anteriormente, visto que o esforço para aumentar a renda da família diante de circunstâncias adversas, como a ida das novas gerações para as cidades, mudam as perspectivas do que é útil para o camponês no seu cotidiano.

O grau de penosidade se eleva em razão do aumento ou diminuição dos esforços para se ter o que é útil na propriedade, nos moldes que se encontra (quantidade de pessoas, renda necessária, quantidade de trabalho complementar dentre outros). Sendo assim, elas se vinculam diretamente à composição da força de trabalho e ao consumo exigido. Quanto menor a força de trabalho, maior a penosidade para satisfazer as necessidades da família, ou o que lhe é útil para se manter.

No caso das propriedades analisadas, o aumento da penosidade se vincula a crescente ida das novas gerações para as cidades em um contexto de readaptação das estratégias e de impacto direto das lavouras de cana no repertório dos camponeses. Apesar da diminuição do consumo na propriedade, no momento de saída dos jovens para as cidades, por vezes se aumentam os gastos com moradia, estudo e serviços, o que tende a elevar a penosidade do camponês por um período indeterminado, a depender do tempo para formação e acesso ao mercado de trabalho por parte do filho.

Já as famílias que contam com o auxílio dos filhos no trabalho e na renda da família têm maiores possibilidades de diminuírem a penosidade dos seus membros, o 
tempo de trabalho de cada um, havendo maior divisão de tarefas e a possibilidade de renda extra fora da propriedade, Mesmo que outro filho tenha ido pra cidade no mesmo período, a necessidade de aumento do trabalho será suprida de forma menos penosa com três ou mais membros.

As necessidades de lazer e descanso dos camponeses é outra variável importante nesse momento. Encontramos, na maioria das propriedades, famílias que assumem não ter atividades de lazer, e tem no trabalho o único que se pode chamar como tal. Os passeios ficam por conta das vezes que é preciso ir à cidade, quando se pode passar um tempo em algum bar, restaurante ou na casa de familiares.

[risos]...nosso lazer é esse aqui mesmo. Não tem muito tempo pra isso não meu filho, tem que trabalhar muito. De vez em quando eu vou na cidade resolver alguma coisa, ai passo na casa dos parentes, tomamos um café e conversamos, mas só mesmo. Antes a gente ia muito na comunidade, tinha festa, ir na igreja, hoje nem missa tem mais, o padre foi embora, ai vamos ficando aqui mesmo. (ENTREVISTA 06, 2018).

A diminuição das atividades de lazer foi algo marcante nas entrevistas. O aumento da penosidade e a relação do que é útil para a família dentro dessa conjuntura, se vinculam diretamente a esse processo. Soma-se a esses fatores a ida dos filhos para a cidade ou mesmo a necessária diversificação da produção.

Em mais de $60 \%$ das propriedades nos foi relatado que as atividades de lazer se resumem em visitar os vizinhos e parentes, e em todas elas ficou evidente que as atividades antes existentes na comunidade já não existem mais. A maioria deles participava das quermesses, dos bailes, terços e festas da escola, porém a maioria dessas atividades acabaram, restando apenas a "festa de São João" realizada na escola e já mencionada anteriormente.

Outros 33\% afirmaram que realizam algumas atividades de lazer nos arredores da propriedade, como a pesca e a caça, esta última comprometida em razão da diminuição da vegetação nativa e da expulsão dos animais. A pesca, apesar de menos frequente, ainda continua sendo realizada.

Meu filho ainda gosta muito de pescar, meu marido também gostava e ele aprendeu com ele. Eu mesmo não vou. Quando vou na cidade gosto de ir num barzinho, comer uma pizza, essas coisas eu faço, mas sempre quando tem alguma coisa pra fazer lá, se não é difícil. (ENTREVISTA 11, 2018)

Nesse sentido, poucos apresentaram aspectos vinculados à manutenção das atividades de lazer na comunidade, e um grande número apontou que não praticam nenhuma dessas atividades, ao menos que tenham que ir à cidade e aproveitam para passar um tempo em locais como pizzarias, bares, lanchonetes e etc. 
O fator renda continua sendo especialmente importante nesse momento. Vê-se que esse equilíbrio abre caminho para uma análise mais integral da unidade, no que é útil para que se mantenha a família camponesa onde estejam seus membros dependentes. A partir desse momento podemos falar das relações que se estabelecem entre a unidade camponesa e seu exterior.

\section{O equilíbrio entre pessoas e natureza nas unidades camponesas}

Uma das principais relações de reciprocidade expressa nas unidades camponesas se vincula à coprodução, ou seja, à produção em conjunto com a natureza. Em todas as unidades analisadas se tem a preocupação constante com a manutenção dos ecossistemas naturais, não só no âmbito da produção, mas também para a qualidade de vida da família.

Nesse sentido, não há aspectos rígidos ou planejamento extremo, visto que as condições são adversas e estão ligadas ao grau de emancipação do campesinato frente ao avanço do território da usina sobre suas propriedades. Porém, podemos observar características em comum em razão dos efeitos da cana sobre seus modos de vida, que se assemelham nas unidades analisadas.

Como já destacado, surgiram novas formas de adaptação nas propriedades a partir da sua relação com a usina, e dentre elas está a percepção do meio ambiente natural, além das mudanças no que se produz e como se produz, posto que a degradação do Cerrado e as técnicas para o plantio da cana impossibilitam alguns tipos de produção em detrimento de outros.

Podemos averiguar a diminuição da produção de algumas frutas e de temperos diversos, pois a necessidade de um ambiente limpo e livre de agrotóxicos faz com que essa produção não ocorra. A pimenta, por exemplo, é cultivada bem mais próxima a residência, assim como algumas frutas, na busca por fugir do veneno lançado pelas aeronaves.

Eles pensam que desligando o motor a 100, 200 metros daqui vai evitar alguma coisa. $\mathrm{O}$ ar não se movimenta não? O que eles jogam lá não vai chegar aqui? A gente presta atenção na natureza, sabe como ela funciona. Um, dois dias depois que avião passa no horizonte, um monte de coisa amadurece, e um dia depois morrem. Só não vê quem não quer. (ENTREVISTA 07, 2018).

Podemos observar no relato a necessidade da coprodução e a importância da percepção da natureza para a produção camponesa. O repertório direcionado à coprodução, em certa medida, aprimora as habilidades dos camponeses, que se reinventam a partir da condição extrema que estão sujeitos. Porém, em mais de $80 \%$ das propriedades foi constatada uma verdadeira incapacidade de se produzir algumas 
culturas, fazendo mudar também o nível de dependência dos recursos externos, que agora são buscados na rede urbana, como as pimentas, temperos diversos e frutas.

A maleabilidade do solo e dos corpos d'água para determinada produção é também dificultada, visto que as nascentes estão diminuindo e a vegetação dá lugar às lavouras de cana. O intenso processo de padronização provocado pela usina leva a diminuição na maleabilidade do solo, dos corpos d'água e da vegetação nativa para a produção.

\begin{abstract}
Esses dias mesmo eles desmataram uma área ali pra baixo com uma nascente linda. É muito triste porque se tira a água, tira as árvores, some tudo. Mas eles não estão preocupados com isso, o dinheiro dominou tudo isso aqui, e a gente não se une, todo mundo reclama, mas não se une. A gente só vai ter força quando lutar junto. (ENTREVISTA 05, 2018).
\end{abstract}

Vê-se que, apesar de repertório vasto, circunstâncias impossibilitam a organização do equilíbrio em razão da forte degradação provocada pela agroindústria canavieira. Cabe ao camponês simplesmente abandonar certas culturas e aumentarem seu grau de dependência, diminuindo assim sua autonomia.

Consideramos o equilíbrio com a natureza extremamente ameaçado na comunidade Boa Esperança, pois apesar da capacidade adaptativa e do aprimoramento das habilidades, o que vemos é uma impossibilidade de produção de forma conjunta com os processos naturais em diversas culturas, delimitando assim o repertório do camponês, sua diversidade e capacidade de produção.

\title{
O equilíbrio entre produção e reprodução nas unidades camponesas
}

Esse equilíbrio se vincula diretamente aos anterior (equilíbrio entre pessoas e natureza). A busca por reprodução social vai depender da capacidade do camponês em fazer sua produção ser um processo contínuo, ou seja, em trabalhar de forma conjunta com a terra para que ela lhe retribua as condições para a próxima etapa.

Além da própria terra e da coprodução, a (re)produção do camponês também está vinculada à continuidade daqueles recursos adquiridos fora da propriedade, como os maquinários conseguidos com mais facilidade através de associações. Apesar do acesso, a abstenção em relação ao auxílio contínuo em momentos posteriores (como a manutenção das máquinas, de cercas e etc.) podem impossibilitar, em curto prazo, que se reproduza as atividades.

Alguns auxílios relacionados à Usina Cerradão foram destacados pelos camponeses da comunidade, porém, eles eram realizados de forma pontual, não havendo 
um monitoramento dos problemas e um acompanhamento sistemático das condições posteriores a essa intervenção.

De vez em quando eles vêm aqui pra tacar veneno nas moscas, ai fica bom por um tempo, mas logo elas já voltam, e ai acabou, demoram um, dois anos pra voltarem. Quando eles chegaram eles falaram que estavam à disposição pra conversar com todo mundo, mas eles fazem de vez em quando, no fundo não tão preocupados. (ENTREVISTA 13, 2018).

O relato demonstra como, no âmbito da produção, algumas ações auxiliam, porém se não houver um acompanhamento sistemático, tal condição simplesmente não se reproduz. As políticas relativas à pequena produção também são um bom exemplo desse processo. Em todas as propriedades ouvimos relatos sobre a atuação do governo municipal na comunidade. A principal reclamação é justamente a pontualidade das ações.

\footnotetext{
$\mathrm{Na}$ época da política todos eles aparecem aqui, prometem um monte de coisa, quando ganham vem perguntar um monte de coisa, a gente reclama, fala que precisa daquilo sempre, que vim uma vez ajuda, mas não resolve, mas não adianta. A gente é sozinho, o agricultor é sozinho e eles tão junto, a usina, o prefeito, tá todo mundo junto e a gente sozinho. (ENTREVISTA 09, 2018).
}

Produção e reprodução são assim pensadas conjuntamente na unidade camponesa. Eles têm plena consciência da necessidade de acompanhamento das políticas e da atuação da usina frente aos efeitos sobre seus territórios, mas a preferência por diretrizes que privilegiam certos aspectos em detrimento de outros são evidentes nesse equilíbrio.

Como se pode observar, a relação entre os recursos internos e externos às propriedades está diretamente vinculada à produção e reprodução das unidades camponesas. A disponibilização desses recursos e as ações paliativas da usina e do governo municipal se relacionam diretamente com esses recursos, de onde eles vêm, como são incorporados, acompanhados e até aprimorados em cada unidade.

$\mathrm{Na}$ comunidade Boa Esperança as duas principais fontes obrigatórias de auxílio na reprodução dos camponeses são percebidas com descaso, e apesar de ações que, em curto prazo, melhorem as condições da propriedade, para se reproduzir conta mais a capacidade de cada camponês a partir dessa ação.

A (re)produção das unidades, portanto não é pensada pela usina e, em muitos aspectos, pelo governo municipal. Em $73 \%$ das entrevistas o caráter pontual das ações foi informado como prerrogativa básica.

Como muita gente aqui depende da usina, todos tem medo de cobrar, de falar dos problemas, e se falam é porque tá atrapalhando muito gente, mas isso precisa ter mais, precisa sempre existir pra nós organizar as coisas, porque desse jeito não resolve nada, os problema volta logo. (ENTREVISTA 13, 2018). 
Apesar desse equilíbrio tem um caráter subjetivo e individualizado, algumas características relacionadas aos impactos da usina, bem como de valorização da pequena produção em detrimento do agronegócio, podem ser mais gerais e terem instrumentos que abranjam um grande número de propriedades. Todas as unidades analisadas têm problemas parecidos em relação à reprodução da unidade.

Nesse sentido, o equilíbrio seguinte traz um panorama dos recursos internos e externos necessários às unidades camponesas da comunidade, demonstrando as condições que aproximam tais camponeses a partir desse equilíbrio, em razão principalmente da condição vivenciada por todos: os efeitos da produção sucroenergética na propriedade.

\section{O equilíbrio entre recursos internos e externos nas unidades camponesas}

Como já citado, as mudanças relativas aos recursos internos e externos se realacionam diretamente às técnicas utilizadas pela usina no cultivo da cana-de-açúcar. Nos últimos anos há uma severa mudança naquilo que é ou pode ser produzido nas unidades, mudando assim a relação entre tais recursos.

Como destacado por Ploeg (2016), esse recurso se resume na escolha ou imposição entre "fazer" e "comprar", ou aqueles que são acessados através do mercado e os que são reproduzidos na própria terra. $\mathrm{O}$ grau de dependência e autonomia da unidade, portanto se relaciona à capacidade de desmercantilização do camponês, buscando concentrar seus recursos na propriedade.

Dentre os recursos produzidos na própria terra, ainda se destacam as hortaliças e os pomares, que em sua maioria contam com árvores de grande porte e nativas, e os derivados do leite.

\footnotetext{
Acho que eu nem lembro tudo que tem aqui no sítio [risos]. No pomar acho que tem laranja, banana, limão, acerola, abacate, pequi, murici, corriola, manga, mamão, camu-camu, coco-da-bahia, jabuticaba, muita gueirova, cajá, jaca, dendê, palmeira imperial, baru, coqueirinho de bassoura, grumixama, lixia, caigaiteira, guapeva, mamacadela, abil, pitanga, caju, goiaba, amora, marmelada do campo, araçá, araticum. Nada disso a gente vende, só come ou doa. (ENTREVISTA 06, 2018).
}

Além disso, os recursos necessários à alimentação animal (a silagem é feita por $40 \%$ dos camponeses entrevistados) são majoritariamente produzidos na propriedade, bem como os compostos para as hortas. Esses produtos são a base do que é produzido e consumido nas propriedades, porém o panorama em relação a esses dois conjuntos de transações vem mudando na comunidade. 
A mudança principal no equilíbrio se vincula justamente aos processos produtivos relacionados à cana. Diversos produtos que antes eram produzidos na própria terra e diminuíam a necessidade de recursos externos, hoje são comprados na rede urbana. Em diversas propriedades até o milho para as galinhas passou a ser comprado na cidade, juntamente com a carne de porco (a suinocultura também era mais presente nas propriedades, $53 \%$ dos camponeses disseram ter deixado essa cultura há pouco tempo).

Hoje a fiscalização pega muito no pé. Eles não fazem nada com a usina, com essa cana aqui desse jeito, mas nós não podemos mais nem ter nosso porco, nossa galinha, que eles já vem exigindo um monte de coisa.

[...] A gente compra quase tudo na cidade hoje, o porco tá sendo por um motivo diferente, mas o resto também ficou difícil. (ENTREVISTA 10, 2018).

O grau de dependência dos recursos de mercado vem aumentando. Em mais de 90\% das propriedades, ao perguntarmos “o que compram na cidade?", nos foi respondido "quase tudo", restando apenas as hortaliças e frutas do pomar, o leite e, onde há produção, mandioca e milho. Porém, os gêneros alimentícios básicos como arroz, feijão, verduras e carnes, assim como os temperos já não são produzidos nas propriedades.

Aumentando o número desses recursos externos e da compra desses produtos no mercado, aumenta-se o grau de dependência das unidades, diminuindo assim sua autonomia. No equilíbrio seguinte discutiremos como se dão esses dois aspectos diante do que foi verificado até aqui.

\section{O equilíbrio entre autonomia e dependência nas unidades camponesas}

O grau de dependência e autonomia, como discutido, corresponde à situação do camponês na estrutura vigente da sociedade, sua condição dentro do modo de produção capitalista, sendo dados a partir das diversas instituições que lhe impõem algum tipo privação, bem como de sua autonomia em relação a elas.

Pensemos em uma situação adversa de crise econômica, qual seria a capacidade de manutenção da propriedade? Qual seu grau de endividamento? Ela se sustentaria por muito tempo com os recursos que tem disponível? Essas são algumas das questões que nos ajudam a pensar esse equilíbrio.

O acesso ao crédito se constitui aspecto importante na comunidade. A partir dele uma série dessas instituições se apropria do produto do trabalho camponês. Através dos juros e tributações, geram dependência durante períodos longos, e acabam influenciando diretamente em todos os equilíbrios. As associações, a prefeitura, a Usina Cerradão, a 
crescente dependência dos mercados da rede urbana são algumas instituições e empresas que estão cotidianamente influenciando e determinando as estratégias na comunidade.

As associações e conselhos são importantes para dar acesso a determinados recursos e auxiliar o camponês, porém devemos considerar as empresas públicas e privadas as quais estão vinculados indiretamente, disponibilizando crédito e oferecendo melhores condições para o produtor, e, por conseguinte, atribuindo-lhe dependência.

Apenas um camponês entrevistado não participa de nenhuma associação ou conselho de pequenos produtores, o qual preferiu não responder o motivo. A Cooperativa Mista dos Produtores Rurais de Frutal - COFRUL tem um número maior de associados, seguido da Associação de Pequenos Produtores da Boa Esperança. Outras associações presentes são a Associação dos Micro e Pequenos produtores de Frutal, O Sistema de Cooperativas de Crédito do Brasil - SICOOB, o Conselho de Agricultura Sustentável de Frutal, a CREDICITRUS e a COOPERCITRUS.

Dentre os motivos relacionados à associação estão os benefícios relativos ao comércio dos produtos e aquisição de maquinários, além de considerarem importante as deliberações que ali ocorrem (20\%).

Participo apenas da COFRUL, porque pra entregar o leite eu preciso participar. Lá eles podem facilitar alguma coisa, dá algum benefício e estamos sempre conversando com o pessoal. As votações também são importantes pra nós, tem coisas importantes pra gente. (ENTREVISTA 10, 2018).

Além do crédito e das associações, podemos citar também a dependência dos recursos da rede urbana, algo já salientado no subitem anterior. A necessidade cada vez maior de gêneros alimentícios e de produtos que já não são produzidos na propriedade aumenta o grau de dependência da unidade.

Observamos uma constante diminuição da autonomia das propriedades em razão dos aspectos citados, alguns mais evidentes com a chegada da usina, outros presentes mesmo em períodos anteriores, mas que ainda comprometem a estabilidade da propriedade e a organização dos equilíbrios.

Nota-se um aumento do poder econômico e político das instituições que "controlam" a produção camponesa, como as multinacionais e empresas financeiras, cercando-a na sua prática cotidiana, bem como no produto de seu trabalho e em toda a dinâmica reprodutiva da unidade. 


\section{O equilíbrio entre escala e intensidade nas unidades camponesas}

Por fim, temos o equilíbrio entre o número de objetos ou instrumentos de trabalho e a força de trabalho relacionada a eles. Como podemos notar, os impactos sobre o meio ambiente natural da comunidade interferem diretamente no fator "escala", visto que grande parte deles faz parte da natureza, provém dela, sendo ela central nessa relação.

A combinação, portanto entre força de trabalho, instrumentos e objetos garantem maior ou menor intensidade de produção. Como vimos, a situação do trabalho nas unidades não é tão alarmante, porém os instrumentos e objetos contam com situações adversas para serem produzidos ou adquiridos.

A escala das propriedades apresentam dados preocupantes em relação à forma de obtenção dos objetos e recursos, visto que a degradação ambiental provocada pela usina impacta diretamente na coprodução e na fonte mais segura de acesso a tais bens, a natureza. Em todas as unidades analisadas, os camponeses responderam que o crescimento das lavouras de cana-de-açúcar interfere de alguma forma na sua propriedade.

Em relação à intensidade, as necessidades momentâneas de aumento no rendimento familiar nos esclarecem sua redinamização. Em períodos específicos as propriedades necessitam de um maior aproveitamento da sua força de trabalho e dos produtos que tem disponível.

Nesse sentido, as circunstâncias pelas quais passam as famílias camponesas são únicas em cada período, necessitando assim de um balanço impossibilitado nesse trabalho. A falta de tempo hábil para a realização desse balanço e das principais interferências na intensidade de trabalho aplicado à produção não nos permite traçar um panorama de como esse equilíbrio está se dando no intervalo de tempo proposto para análise.

Alguns pontos importantes ressaltados pelos camponeses para que lhe façam "trabalhar mais" foram o estudo dos filhos e o momento de ida pra cidade, quando determinada produção lhe rende menos que o esperado e se deve compensar em momentos posteriores, e o período de estiagem, que os fazem buscar alternativas para além daquelas já incorporadas à propriedade.

Diante da análise, teceremos a seguir alguns comentários a respeito da ressignifação da comunidade Boa Esperança e do município de Frutal no cenário atual, bem como os aspectos simbólico-culturais que (re)existem na comunidade. 


\section{Considerações finais}

A partir da análise realizada, pudemos constatar ressignificações incorporadas ao campesinato e à comunidade Boa Esperança neste início de século. A fragilidade com que estão se dando alguns dos equilíbrios demonstra como o setor sucroenergético interfere diretamente nos modos de vida e na reprodução social dos camponeses da comunidade.

Os processos de modernização agrícola e incorporação contínua de tecnologia nos processos produtivos imprimiram uma forte transformação no território camponês. Alguns dos equilíbrios são facilmente afetados pela condição que ocupam, já outros resumem em grande medida a situação enfrentada por todos eles, como é o caso do grau de autonomia e dependência, bem como de produção e reprodução da unidade. O primeiro esclarece como a relação entre recursos internos e externos, bem entre pessoas e natureza, podem gerar graus diferenciados de dependência mercantil, e podem ser resumidos a partir de aspectos como renda, consumo e trabalho.

Já o segundo aponta que, apesar de terem acesso à alguns bens de produção, a capacidade de (re)produzir tais bens para que se continue a produzir depende de uma série de outros fatores, os quais também se vinculam aos outros equilíbrios. A interligação entre eles pode resumir, até certo ponto, a condição de cada uma das unidades ou mesmo do seu conjunto, por estarem sujeitos a processos relacionados.

A dinâmica territorial incorporada pela agroindústria transforma continuamente os territórios camponeses da comunidade Boa Esperança, e tal embate foi discutido no trabalho à luz do desenvolvimento do agronegócio no campo do município de Frutal (MG). Nota-se que as mudanças técnico-produtivas implementadas pela agricultura empresarial têm forte ligação com a reprodução dos camponeses, especificamente quando analisamos seus equilíbrios e as características das transformações a eles vinculadas.

Deve-se ressaltar a limitação da análise de alguns elementos em razão do tempo de pesquisa. Os balanços percebidos minimamente nos equilíbrios podem necessitar de um tempo maior para melhor serem apreendidos e analisados, podendo assim descrever de forma mais ajustada e em longo prazo a diversidade da produção camponesa. Porém, consideramos ter apreendido aspectos importantes em relação à reprodução do campesinato na comunidade, trazendo elementos novos para a realidade estudada e para a região, algo ainda pouco averiguado nos estudos acadêmicos e empíricos. 
Nesse sentido, a análise dos equilíbrios camponeses a partir de Ploeg pode nos oferecer resultados mais precisos em um intervalo de tempo maior, a partir de um monitoramento do trabalho, das atividades produtivas, das transformações e das relações estabelecidas na propriedade. Alguns equilíbrios apresentados necessitam de uma análise mais aprofundada, com maiores evidências do funcionamento de cada unidade e da relação com seu exterior.

Notamos que o município de Frutal apresenta elementos para entendermos a dinâmica de unidades camponesas a partir de seu embate com o setor sucroenergético. As especificidades aqui encontradas podem levar a um avanço da própria teoria de Ploeg, bem como da compreensão dos diferentes territórios em disputa, suas características e sua organização na atual conjuntura do município e do agronegócio nacional.

São comuns diversos dos impactos e estratégias do campesinato a partir desse embate. Os equilíbrios da unidade camponesa, para além da organização, expressam, ao nível mais elementar, a constituição da comunidade e do modo de vida camponês. Através deles podemos buscar dados sobre a produção e a reprodução desse grupo, mas também entender de forma clara quais os caminhos e os anseios desse tipo de produção a partir do lugar que ocupam na sociedade capitalista moderna, e como seus multiterritórios se articulam e se reinventam no século XXI.

\section{Notas}

\footnotetext{
${ }^{1}$ Expressão de autoria de José de Souza Martins, utilizada em seu capítulo: MARTINS, José de S. Terra de negócio e terra de trabalho: contribuição da questão agrária no Brasil. In: violência: a questão política no campo. 2.ed.São Paulo: HUCITEC,1982. p.45-66.

${ }^{2} \mathrm{O}$ distrito é uma subdivisão do município e possui características de área urbana.

3 Adota-se aqui o termo "comunidade" para um pequeno aglomerado de casas e pessoas na zona rural, juntamente com as propriedades circundantes.

${ }^{4}$ Adota-se aqui os equilíbrios identificados e trabalhados por Ploeg (2016), os quais serão aprofundados em tópicos seguintes.

${ }^{5}$ Ethrel é um regulador de crescimento do grupo etileno e tem como objetivo acelerar a maturação da cana e inibir o florescimento, além de proporcionar qualidade para os fins propostos. O composto é aplicada nas lavouras através de aeronaves.

${ }^{6}$ Escola instalada na comunidade pelo seu fundador homônimo, no ano de 1959, e que ainda atende entre 150 e 250 alunos.

${ }^{7}$ Resíduo pastoso e malcheiroso que sobra após a destilação fracionada do caldo de cana-de-açúcar fermentado para a obtenção do etanol.
}

\section{Referências}

CAMPOS, Natália Lorena. Redes do agronegócio canavieiro: a territorialização do grupo Tércio Wanderley no Triângulo Mineiro/Alto Paranaíba. 2014. 209 f. Dissertação (Mestrado) - Curso de Geografia, Instituto de Geografia, Universidade Federal de Uberlândia, Uberlândia, 2014. 
CHAYANOV, A. V. La organización de la unidad económica campesina. Buenos Aires: Ediciones Nueva Visión, 1974

COSTA, Francisco de Assis; CARVALHO, Horácio Martins de. Campesinato. In: STEDILE, João Pedro (Org.). A questão agrária no Brasil 9: Interpretações sobre o camponês e o campesinato. São Paulo: Expressão Popular, 2016. Cap. 1. p. 23-34.

ELIAS, Denise. Globalização e agricultura: a região de Ribeirão Preto - SP. São Paulo: Edusp, 2003. 400 p.

ELIAS, Norbert; SCOTSON, John L. Os estabelecidos e os outsiders: Sociologia das relações de poder a partir de uma pequena comunidade. Rio de Janeiro: Jorge Zahar, 2000.

FERNANDES, Bernardo Mançano. Sobre a tipologia de territórios. In: SAQUET, Marcos Aurélio; SPOSITO, Eliseu Savério (Org.). Territórios e territorialidades: teorias, processos e conflitos. São Paulo: Expressão Popular, 2009. Cap. 9. p. 197-215.

FERNANDEZ, V. R.; BRANDÃO, Carlos. Escalas y políticas del desarrollo regional: desafios para América Latina. 1. ed. Buenos Aires / Madrid: Mi-o y Dávila, 2010. v. 1. 279 p.

FREDERICO, Samuel. O novo tempo do Cerrado: expansão dos fronts agrícolas e controle do sistema de armazenamento de grãos. São Paulo: Annablume, 2010.

GIL, Antonio Carlos. Métodos e técnicas de pesquisa social. 5. ed. São Paulo: Atlas, 1999.

HAESBAERT, Rogério. Territórios alternativos. São Paulo: Contexto, 2002.

HAESBAERT, Rogério. O mito da desterritorialização: do "fim dos territórios" à multiterritorialidade. 3 ed. Rio de Janeiro, 2007.

IANNI, Octavio. A utopia camponesa. In: STEDILE, João Pedro (Org.). A questão agrária no Brasil 9: Interpretações sobre o camponês e o campesinato. São Paulo: Expressão Popular, 2016. Cap. 3. p. 55-70.

INSTITUTO BRASILEIRO DE GEOGRAFIA E ESTATÍSIRCA (IBGE). Produção Agrícola Municipal (PAM). Rio de Janeiro, 2007.

. Produção Agrícola Municipal (PAM). Rio de Janeiro, 2010.

. Produção Agrícola Municipal (PAM). Rio de Janeiro, 2014.

. Produção Agrícola Municipal (PAM). Rio de Janeiro, 2016.

KAUTSKY, Karl. A questão agrária. Tradução de Otto Erich W. Mass. São Paulo: Nova Cultura, 1986. (Os economistas). 
LENIN, V. I. O desenvolvimento do capitalismo na Rússia. Tradução de José Paulo Netto. São Paulo: Nova Cultural, 1980. v. 1 (Os economistas).

MARCONI, Marina de A.; LAKATOS, Eva M. Fundamentos de metodologia científica. 7 ed. São Paulo. Atlas S.A, 2010.

MARQUES, Maria Inez Medeiros. A atualidade do conceito de camponês. In: STEDILE, João Pedro (Org.). A questão agrária no Brasil 9: Interpretações sobre o camponês e o campesinato. São Paulo: Expressão Popular, 2016. Cap. 2. p. 35-53.

MARTINS, José de Souza. A chegada do estranho. São Paulo: Hucitec, 1993.

MENDES, Heitor Nascimento. Expressões territoriais camponesas da comunidade Boa Esperança/Frutal (MG): os equilíbrios da unidade camponesa frente ao avanço do agronegócio canavieiro. 2018. 153 f. Dissertação (Mestrado) - Curso de Geografia, Instituto de Geografia, Universidade Federal de Uberlândia, Uberlândia, 2018.

MORAES, Antonio Carlos R.; COSTA, Wanderlei M. da. O ponto de partida: o método. In: _. Geografia crítica: a valorização do espaço. São Paulo: HUCITEC, 1984. p. 26-34.

Bases da formação territorial do Brasil. O território colonial brasileiro no "longo" século XVI. Hucitec: São Paulo, 2000.

OLIVEIRA, Ariovaldo Umbelino de. A agricultura camponesa no Brasil. 2. ed. São Paulo: Contexto, 1996. 164 p.

PLOEG, Jan Douwe van Der. Camponeses e a arte da agricultura: Um manifesto chayanoviano. São Paulo; Porto Alegre: Unesp; Ufrgs, 2016.

RAFFESTIN, Claude. A produção das estruturas territoriais e sua representação. In: SAQUET, Marcos Aurélio; SPOSITO, Eliseu Savério (Org.). Territórios e territorialidades: teorias, processos e conflitos. São Paulo: Expressão Popular, 2009. Cap. 1. p. 17-35.

SAQUET, Marcos A. Abordagens e concepções de território. São Paulo: Expressão Popular, 2007.

SOUZA, Andrezza Gomes de. A territorialização do agronegócio canavieiro em Frutal - MG. 2012. 186 f. Dissertação (Mestrado) - Curso de Geografia, Universidade Federal de Uberlândia, Uberlândia, 2012.

STEDILE, João Pedro (Org.). A questão agrária no Brasil 9: Interpretações sobre o camponês e o campesinato. São Paulo: Expressão Popular, 2016.

Recebido em 31/12/2019.

Aceito para publicação em 19/05/2020. 